\title{
latrogenic profunda femoris artery pseudoaneurysm: late presentation with successful endovascular microcoil embolisation
}

\author{
Niraj Nirmal Pandey, Sreenivasa Narayana Raju, Rengarajan Rajagopal, Sanjeev Kumar
}

Cardiovascular Radiology and Endovascular Interventions, All India Institute of Medical Sciences, New Delhi, Delhi, India

\section{Correspondence to} Dr Sanjeev Kumar, sanjeevradio@gmail.com

Accepted 21 November 2018

\section{DESCRIPTION}

An 85-year-old man suffered an intertrochanteric fracture of the right femur following a fall in bathroom. The patient underwent fixation of fracture with dynamic hip screw and barrel plate on the next day following trauma (figure 1A,B). The postoperative course was uneventful.

The patient presented back to the outpatient clinic 6 months later with a large, expansile, non-pulsatile swelling over the anterolateral aspect of the upper third of right thigh. The patient gave history of having first observed a small swelling in the region 15 days postfixation which gradually increased in size along with increasing severity of pain. No signs of distal ischaemia were present. An ultrasound (US) Doppler examination revealed a well circumscribed, peripherally thrombosed pseudoaneurysm in the intramuscular compartment of right thigh measuring $9 \times 6 \times 7 \mathrm{~cm}$ with the patent flowing part measured $2.3 \times 2.8 \times 3.3 \mathrm{~cm}$. The vessel of origin could not be accurately delineated for which the patient further underwent a CT angiography (CTA).

CTA demonstrated the pseudoaneurysm to be arising from a lateral muscular branch of the right profunda femoris artery (PFA) (figure 1C,D). The patient was planned for a digital subtraction angiography and coil embolisation of the pseudoaneurysm. Selective angiography performed via a contralateral transfemoral arterial access delineated

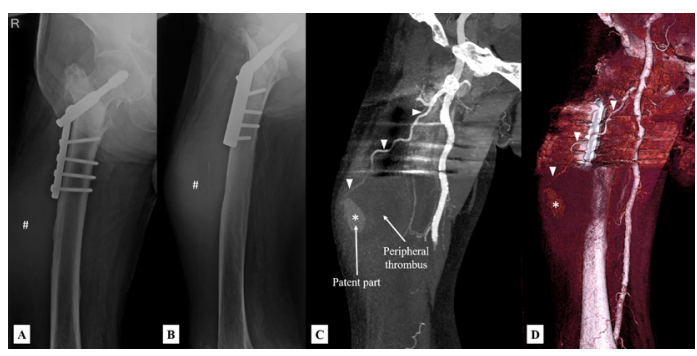

Check for updates

(C) BMJ Publishing Group Limited 2018. No commercial re-use. See rights and permissions. Published by BMJ.

To cite: Pandey NN, Raju SN, Rajagopal R, et al. BMJ Case Rep 2018;11:e228314. doi:10.1136/bcr-2018228314
Figure 1 Radiographs of the right hip joint in the anteroposterior $(A)$ and oblique $(B)$ view at the time of presentation reveal successful fixation of the intertrochanteric fracture with a dynamic hip screw and fixed angle barrel plate. A soft-tissue swelling (\#) is noted along the anterolateral aspect of thigh. CT angiography maximum intensity projection image (C) and volume rendered image (D) delineate the pseudoaneurysm $\left({ }^{*}\right)$ arising from a lateral muscular branch of the right profunda femoris artery (arrowheads). Note made of extensive streak artefact due to metallic prostheses.

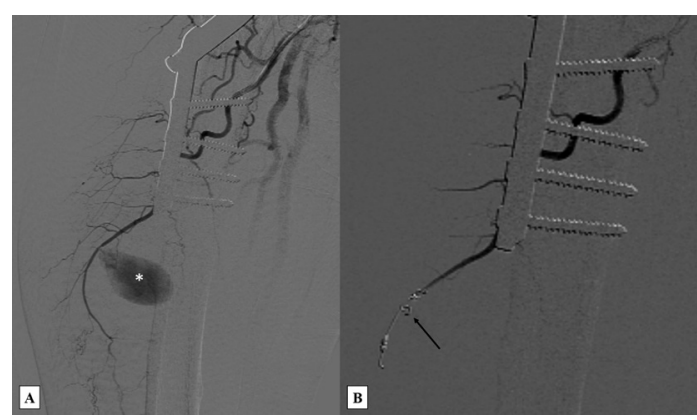

Figure 2 Digital subtraction angiography (A) after superselective cannulation of the lateral muscular branch of the right profunda femoris artery shows filling of the pseudoaneurysm $\left({ }^{*}\right)$. Postembolisation digital subtraction angiography (B) shows multiple microcoils in the feeding vessel both proximal and distal to the site of origin of pseudoaneurysm (black arrow) with no filling of the pseudoaneurysm sac.

the pseudoaneurysm with a very narrow neck arising from the muscular branch of the right PFA. Superselective catheterisation of the feeding vessel was performed with the use of a 2.8 Fr microcatheter inserted coaxially through a 5 Fr catheter. The artery was embolised both distal and proximal to the site of origin of pseudoaneurysm with multiple 0.018-inch platinum Hilal Embolization Microcoils (Cook, Bloomington, Indiana, USA). Postembolisation angiogram showed no filling of the pseudoaneurysm (figure 2A,B). Follow-up US Doppler examination confirmed complete thrombosis of the pseudoaneurysm sac.

Occurrence of pseudoaneurysms of the PFA is an uncommon but documented complication following fractures and orthopaedic procedures in the upper thigh. They have been reported following various orthopaedic procedures including external fixation of femur, core decompression and internal fixation of the proximal femoral fractures. ${ }^{1}$ Pseudoaneurysms can result secondary to injury to PFA due to a spike of fractured bone, displaced implants, retractors, protruding cortical screw tip, gamma nail or overpenetration by a drill bit. ${ }^{2}$

Although the approach to treatment is dictated by numerous factors, the size of the pseudoaneurysm remains the single most important determinant. ${ }^{3}$ Small (up to $2-3 \mathrm{~cm}$ ) and asymptomatic pseudoaneurysms may be simply observed as they often thrombose spontaneously. Larger and symptomatic pseudoaneurysms may be treated with US-guided obliterative compression, direct US-guided 
thrombin injection, endovascular management using stentgraft placement or coil embolisation or open surgical repair. ${ }^{1}$ Recently, endovascular management is the preferred modality of treatment with surgery reserved for cases not amenable to embolisation. $^{2}$ An important point of consideration is the well-developed collateral supply of the PFA which makes it necessary to embolise the feeding vessel both proximal and distal to the

\section{Learning points}

- Profunda femoris artery pseudoaneurysms are an uncommon but well-recognised complication following fractures and orthopaedic procedures in the upper thigh, including external fixation of femur, core decompression and internal fixation of the proximal femoral fractures.

- Endovascular management, including coil embolisation or stent-graft placement, is the preferred modality of treatment with surgery reserved for cases not amenable to embolisation.

- Profunda femoris artery has a well-developed collateral supply, which makes it necessary to embolise the feeding vessel both proximal and distal to the pseudoaneurysm to completely exclude it from the circulation. pseudoaneurysm to completely exclude it from the circulation by preventing backflow from the collateral circulation. ${ }^{1}$

Contributors NNP has participated sufficiently in the conception of the idea, development of the intellectual content, design, writing and final approval of the manuscript. SNR has participated sufficiently in the conception of the idea, development of the intellectual content, design, writing and final approval of the manuscript. RR has participated sufficiently in the conception of the idea, development of the intellectual content, design, writing and final approval of the manuscript. SK has participated sufficiently in the conception of the idea, development of the intellectual content, design, writing and final approval of the manuscript.

Funding The authors have not declared a specific grant for this research from any funding agency in the public, commercial or not-for-profit sectors.

Competing interests None declared.

Patient consent for publication Obtained

Provenance and peer review Not commissioned; externally peer reviewed.

\section{REFERENCES}

1 Roy KD, Aggarwal RA, Purohit S, et al. latrogenic pseudo-aneurysm of profunda femoris artery following fixation of intertrochanteric femur fracture - A case report and review of literature. J Clin Diagn Res 2016;10:RD01-3.

2 Biswas S, McNerney P, Kiproff P. Pseudoaneurysm of the profunda femoris artery following blunt trauma treated by endovascular coil embolization: review of two cases and relevant literature. Case Rep Emerg Med 2017;2017:1-6.

3 Dillon JP, O'Brien GC, Laing AJ, et al. Pseudoaneurysm of the profunda femoris artery following an inter-trochanteric fracture of the femur. Injury Extra 2004;35:30-2.

Copyright 2018 BMJ Publishing Group. All rights reserved. For permission to reuse any of this content visit

https://www.bmj.com/company/products-services/rights-and-licensing/permissions/

BMJ Case Report Fellows may re-use this article for personal use and teaching without any further permission.

Become a Fellow of BMJ Case Reports today and you can:

- Submit as many cases as you like

- Enjoy fast sympathetic peer review and rapid publication of accepted articles

- Access all the published articles

- Re-use any of the published material for personal use and teaching without further permission

For information on Institutional Fellowships contact consortiasales@bmjgroup.com

Visit casereports.bmj.com for more articles like this and to become a Fellow 